\title{
The ongoing contributions of spin-off research and practice to understanding corporate restructuring and wealth creation: $\$ 100$ billion in 1 decade
}

\author{
James E. Owers ${ }^{1,2} \&$ Bruno S. Sergi (iD ${ }^{1,3 凶}$
}

Since the 1980s, analysis of spin-offs has become a key line of inquiry in corporate finance. This paper reviews the theory and empirical research papers about spin-off restructuring and measures the monetary value created by spin-offs. First, we document the valuation impact of spin-offs for the divesting firms and then examine such subtleties as the interesting (positive) ex-dividend day price impact and the myriad other details associated with these transactions. This study provides a review of the now extensive research into spin-off divestitures. It looks into equity price reactions around the announcements of 249 voluntary spin-offs undertaken by US public companies over the interval 2007-2017. The abnormal returns associated with recent spin-off divestitures are of the same order of magnitude as those from the earlier papers, showing the sustained statistical significance and new economic materiality measures. With more firms undertaking spin-offs and the positive abnormal returns continuing to be substantial, the clear implication is that the overall monetary value creation resulting from spin-offs has increased markedly. Finally, and in a first for spinoff research, this paper calibrates the monetary value created by spin-offs despite the voluminous research of the topic. It establishes that spin-offs create large monetary value increments for divesting a firm's stockholders-almost $\$ 100$ billion in the interval 2007-2017.

\footnotetext{
${ }^{1}$ Harvard University, Cambridge, MA, USA. ${ }^{2}$ Georgia State University, Atlanta, GA, USA. ${ }^{3}$ University of Messina, Messina, Italy. ${ }^{凶}$ email: bsergi@fas.harvard. edu
} 


\section{Introduction}

here is a very high level of corporate restructuring globally. Changes in the control of corporate assets include both mergers and acquisitions (M\&A) and divestitures. M\&A activity attracts a great deal of attention in the financial press, noting, for example, that the total value of such activity in the USA in 2018 was $\$ 3.88$ trillion, exceeded only by the total in 2015 of $\$ 4.77$ trillion.

While M\&A activity gets the most attention, divestitures (primarily spin-offs and sell-offs) also result in extensive changes in control of corporate assets. Some calibrations find divestiture activity to be in the order of one-third of the total value of M\&As. A dramatic signal of the rapidly increasing role of spin-offs in corporate restructuring is the change in the Bloomberg U.S. Spinoff Index (BNSPIN). It tracks the market capitalization of units spun-off from U.S. public companies and has a market "cap" of $>$ $\$ 1$ billion. In the financial press, the investment performance of spin-off firms has been receiving ever-growing attention. This is not surprising when the BNSOIN index companies had generated a total return since 2003 (when the index started, signaling the growing role of spin-offs) of $1030 \%$. Over the same interval, the S\&P Index has returned 194\%. 2018 was a banner year for spinoffs. There were almost twice as many significant public company spin-offs $(n=13)$ compared with 2017.

Restructuring is an ongoing process whereby firms seek the optimal combination of strategic business units (SBUs) to maximize their shareholders' value. There is a well-documented, top level ongoing restructuring. M\&As get most of the headlines' attention, although divestiture transactions involving parts of firms are equally significant for the firms involved. Divestitures are predominantly either sell-offs or spin-offs. Sell-offs are relatively straightforward transactions wherein a firm sells a SBU to another firm, typically for cash consideration, but occasionally with a more complex payment set.

Spin-off divestitures do not involve negotiating with another firm. Instead, after undertaking a review of its industrial organization, a company can decide to separate business unit(s) and create separate firms for those. The ownership of the newly created public company is distributed as a special dividend to the original "parent" firm's shareholders. The immediate effect is to provide increased potential for shareholders to revise their portfolios. This added investment opportunity set for investors is reflected in the intrinsic value enhancement resulting from the organization for the improved set of SBUs, and the separation out of parts(s).

Spin-off restructuring has a long history in practice, but historically, this divestiture strategy was low. Despite the long history of some voluntary spin-off divestitures level, they have received rigorous research interest only since the early 1980s. The foundational papers by Hite and Owers (1983) and Schipper and Smith (1983) are widely considered to be the first substantive works on the topic. Since that time, there has been an ongoing stream of research into the various aspects of spin-offs, to the extent that the original papers have been cited in $>1000$ published articles. Moreover, the stream of research continues.

Corporate divestitures by way of the spin-off have received less attention, e.g., Ellert (1976), Kummer (1976), and Boudreaux (1975), where the focus was on antitrust enforcement effects, in contrast to the much more widely used strategy of voluntary spinoffs (Owers, 1982).

Hite and Owers (1983) find that the size of an average spin-off in their sample is $6.6 \%$ of the divesting firm's original equity value and is associated with an abnormal return of $7.0 \%$ from 50 days before the announcement through completion of the spin-off. The similarities of these magnitudes have an important implication. On average, the divesting "parent," which is smaller after the spin-off, is still worth approximately what it was when the now divested unit was still part of the firm. Some reason that the "parent" shareholders get the shares in the spun-off firm "for free." This is a significant indication of the significance of firms having the optimal industrial organization.

There is the potential for "wealth transfers" from bondholders to stockholders with spin-off transactions, and there are some notable instances where that has occurred, such as the prominent Marriott spin-off in 1993. Several theoretical frameworks support the hypotheses of wealth transfers resulting from spin-offs. For example, Galai and Masulis (1976) describe one such implication where the stockholders have 'stolen away' a portion of the bondholders' collateral since they no longer have any claim on the assets of the new firm. While the potential for claims dilution is most significant for a spin-off, Kim, McConnell, and Greenwood (1977) show that it is also present with creating an autonomous subsidiary case. However, Hite and Owers (1983) found no evidence to indicate the gains to stockholders represent wealth transfers from senior security-holders after looking at all the senior securities of their sample of firms.

The role of this paper is to review the trajectory of academic research on spin-offs and to re-examine some of the previous findings on the valuation consequences of spin-offs, and investigate how the consequences of spin-offs have changed over the years. This paper will contribute a major additional dimension to the calibration of the monetary value created by spin-off transactions. Taking a sample of spin-offs by Center for Research on Security Prices at the University of Chicago (CRSP) followed firms over the interval from 2007 until 2017, we examine a sample of 249 spin-off transactions. This number suggests that the rate of spin-offs has increased along with their visibility in the prominent research literature and interpretation of the findings for the practicing professional audience who advise firms on value maximization and the role of spin-off restructuring in that pursuit.

We find that spin-offs continue to be a significant value creation strategy for both economic and statistical benchmarks/criteria. We find abnormal returns of $3.06 \%$ over the $(-1,+1)$ interval. As in previous research findings (Owers, 1982; Vijh, 1994; Prezas and Symonian, 2015; and Teschner and Paul, 2020), there are significant abnormal terms on the ex-dividend day. Given that this date is known with precision in advance, it requires more than the standard rational expectations perspectives to explain this finding. In summary, we find that spin-off restructuring remains overwhelmingly a value-creating strategy.

The paper is organized as follows. In the next section we undertake an analysis of spin-offs and their role in corporate restructuring. The paper then describes in section "Spin-off research" over the years the sample selection process, with the resulting 249 spin-offs between 2007 and 2017. The methodology employed is then detailed in section "Sample and Data." Finally, the results are present for five analyses: (i) the valuation impact at announcement; (ii) the value changes at the formal announcement of the spin-off dividend; (ii) the abnormal returns at the exdividend date for the upcoming spin-off; (iv) the average abnormal returns over the entire interval from the first announcement in the financial press about a prospective spin-off, through to the final payment of the corresponding dividend; and (v) calibration of the monetary value created by spin-offs.

This paper provides evidence of the monetary economic materiality of value changes associated with spin-offs besides calibrating their statistical significance in explaining the abnormal returns calibrated. Finally, we conclude with a summary. 


\section{An analysis of spin-offs}

Divestitures of corporate assets can use various techniques, the most popular of which are sale divestitures and spin-offs. With a spin-off divestiture, the assets divested are transferred to a newly organized and separated corporation. This feature distinguishes spin-offs from a sale divestiture, which results in the exchange of one asset for another without reducing the original firm's size. Here we shall refer to the unit spun off as the "subsidiary" and the surviving divesting firm as the "parent." If there are no synergies or diseconomies between the parent and subsidiary, and in the absence of cooperation and a frictionless capital market, the spinoff would not be expected to affect valuation. However, the evidence indicates that the prior-spinoff Industrial Organizational form was not optimal that the "parent" and "subsidiary" are, in sum, worth more than the original firm (Stevenson and Eilertsen, 2020; Pearcell and Patel, 2021; Navatte and Schier, 2017).

In large and diversified firms, the increment of incomprehensible information pressurizes the managers for competitive purposes. In contrast, the investors and analysts go for transparent information by which they can comprehend and evaluate the firm. This is illustrated by the anecdote where some financial analysts discontinued following GE (before its recent downsizing) because of the lack of transparency in its financial reporting. Therefore, according to Bergh et al. (2020), it is essential to conceive and test alternative resolutions to the 'Information Disclosure Dilemma' and its connection to firm performance.

Using the context of corporate divestitures, a study by Sana Chiu (2020) conceptualizes firms' advice-seeking as a function of experiential learning, inter-corporation imitation, and sell-offs and spin-offs as seeking advice play a significant role in decision making.

Effect on existing contracts. Specialized sets of contracts provide the divestiture impetus, although restrictive covenants in the bond indenture can limit spin-off effects on the cashflows to bondholders. While covenants directly prohibiting spin-offs are rarely used except with secured debt (e.g., mortgage bonds), indirect controls are operating through dividend restrictions (Smith and Warner, 1979; Kalay, 1982). While Kalay documents it is not unusual for firms to maintain positive reservoirs over the minimum amount specified by prior restrictions, the sale of assets and payment of a cash dividend or repurchase of shares could reduce the reservoir (Dann, 1981; Vermaelen, 1981). This may have adverse tax consequences for the firm and its stockholders or increase costs associated with dividend laundering of the MillerScholes (1978) variety.

Moreover, family firms and stock market performance of acquisitions and divestitures show that when family firms collaborate with non-family firms, the shareholder returns are highest. On the other hand, divestor shareholder returns are highest when family firms sell the business to non-family firms (Feldman et al., 2019).

Value creations through spin-offs show that the abnormal returns do not seem to be related to the factors such as a rise in industrial or geographical focus, information asymmetry, and the amount of a parent company's bank debt (Chai et al., 2017).

A positive influence on the parent firm is noticed on the share prices, and the average abnormal return (AAR) collectively is on the highest side. Therefore, most spin-off research aims to analyze the impact of spin-offs on the share prices affecting the shareholders' wealth (Aggarwal and Garg, 2019).

Another study shows that the post divestiture long-run abnormal returns of sell-off parents are larger than those of carve-out parents. Moreover, there is positive connectivity between post divestiture long-run returns and diversification discount (Pham et al. 2020).

Effect on future contracting flexibility. An alternative explanation for spin-offs is the potential for increasing future contracting flexibility. The set of contracts making up the firm might influence the stockholders' wealth. Jensen and Meckling (1976), Myers (1977), and Smith and Warner (1979) argue that the nature of the operations affects the optimal set of contracts and existing assets, etc. Cross-sectional variations in contracting patterns may be attributed to firm-specific factors. The optimal set of contracts for the combined operations may prevent contracts that would be optimal for the separate activities where they to be conducted by free standing units. This would become especially important as the various units' opportunity sets shift through time. A spin-off would allow the parent and subsidiary to specialize in the contracts they have a comparative advantage. In sum, if the gains in contracting efficiency outweigh the costs of writing and enforcing an additional set of contracts, the stockholders' wealth will be higher.

\section{Spin-off research over the years}

While very small studies of spin-offs can be found in the research literature as early as the mid-1970s (Boudreaux, 1975), the earliest works focused on forced divestitures. The foundational works on voluntary spin-offs are Hite and Owers (1983) and Schipper and Smith (1983). Since that time, extensive and ongoing research into both spin-off and sell-off divestitures has seen numerous investigations of their valuation consequences and many other features of these transactions. For example, Vijh's paper (1994) on the curious ex-dividend day effect with the spin-off was first identified by Owers (1982). In addition, with sell-off divestitures, several studies have investigated the SIC codes of the sellers, buyers, and SBU traded to seek to explain the notable difference between the valuation consequences of sell-offs divestitures of parts of firms and mergers and acquisitions that involve the sale and purchase of whole firms. It has long been documented in the financial economics literature that with whole-firm acquisitions, the overwhelming profile of consequences is that selling/target firm's stockholders enjoy gains while buying/acquiring firms' shareholders typically incur losses. In marked contrast, with partfirm divestiture, the profile of valuation consequences is that both firms enjoy gains.

The hypotheses put forward seeking to explain these notable differences typically focus on (i) the private party nature of many sell-off divestiture transactions is in contrast to the public ("auction") market context of whole-firm acquisitions of publicly traded firms; and (ii) that in divestitures firms buy only units that are similar to their present operations, and can make highervalued uses of them than the (may be more diversified) selling firm. There is thus an increment of value that can be shared in the sell-off negotiations.

The announcement effects of both are statistically significant, but a proper calibration of its magnitude has not previously been undertaken. For spin-offs, the valuation impacts are significantly larger. These findings are in line with Rosenfeld (1984) and point to their robustness over time while using a larger sample. Besides, spin-offs are typically significantly larger as a percentage of the firm is divested compared to sell-offs (the average portion of a firm divested in a spin-off was found approximately $7 \%$ of the company's total assets in Hite and Owers, 1983).

A general conclusion from the divestiture research is that value creation is larger with spin-offs. The major realignment of firms' industrial organizations undertaking spin-offs is that these transactions create substantial value. Explanations for the value 
creation associated with spin-offs include: (i) addressing diseconomies of scale and/or inefficient real-asset diversification; (ii) addressing or pre-empting legal issues; (iii) separating out troubled SBUs; and (iv) and potentially creating smaller firms that will appeal targets for acquisition by other firms in the industry. A classic example of this was when Time Warner spun-off the cable unit. A few years later, it received takeover bids and was eventually acquired. This spin-off thus created two rounds of value creation for the shareholders of Time Warner: (i) at the time of the original spin-off (2009), and (ii) when the spun unit became a target in 2014 and shareholders experienced a 25\% further increase in value.

Compare the consequences of spin-offs and sell-offs, Prezas and Simonyan (2015) find that: (i) after controlling for various firms and divested assets' characteristics, the pre- divestiture market valuation of divesting firms is a significant determinant of announcement effects (they find a negative relationship between the two); and (ii) firms that announce divestitures of underperforming assets realize more significant announcement effects.

An examination of the corporate parent and divested unit Governance Mechanisms (Waldron, 2020) mentions that the governance choices span beyond the choice of a discrete governance mode and compares and contrasts the inter-relationship of individual divested units and their parent companies. Helwege and Liang (2004) and Lowry (2003) hypothesize that divesting firms have an incentive to spin off their assets during periods of optimism as investors are likely to value the shares of new firms higher (see also Baker and Wurgler, 2006).

\section{Sample and data}

The sample identification process involved the following steps:

1. All the data on this study was derived from the CRSP database, maintained by the University of Chicago Booth School of Business.

2. The study examines spin-offs from 2007 until 2017 (inclusive).

Thus, the date range $01 / 2007$ to $12 / 2017$ is examined, and within that, we choose distribution codes for DIST events: Acquisition/Reorganizations (3000-3999).

3. Transactions from the CRSP data with distribution codes: $3762,3763,3764,3862,3863$, and 3864 are identified. These several codes capture spin-off distributions under several terminological sun-categories, including dividends in the stock of another company, special dividends, non-cash distributions. They enabled us to identify all spin-offs by listed companies.

4. The initial press date for each transaction is identified. This involves an exhaustive review of financial news and data sources. The initial press date is the first date on which the intent to have a transaction is announced.

5. To identify the initial press, each company's press releases on the list are reviewed through news sources such as The Wall Street Journal, Reuters, Businesswire, and The New York Times.

6. In employing the EVENTUS econometrics analysis, we impose the following estimation options: end before Event Date: -46 days; minimum estimation length: 3 days; maximum estimation length: 255 days. Autodate: None. Estimation method: OLS.

7. The event period is defined as beginning 30 days before the specific event reexamined (day -30) and ending 30 days after $(+30)$. There was no overlap with the estimation period. The event-window parameters examined reflected customary intervals for event analysis: 50,$0 ;-10,0 ;-5,0$; $-1,0 ;-1,+1 ; 1,5$.

\section{For the tests the Patell metric is chose.}

This procedure generates a sample of 249 after the customary event-study checks (e.g., for confounded events) are undertaken. The interval covered by the study includes the economic perturbation widely referred to as the "great recession." During 2007 and 2008, $n=37$ companies in our sample undertook spin-offs. This is slightly lower than the average of $n=22$ per year over the 11 years covered by the sample.

The results presented below identify cases where returns data insufficiency prevented firms from undertaking spin-offs from being in the empirical sample. First, we find the transaction's initial press date for the company transactions separated using the distribution codes above. The initial press date is the first date on which it announces the intent to have a transaction. These initial "press dates" were gleaned from an online review of all the customary sources of such information (WSJ Index, etc.).

\section{Methodology}

The event-time methodology used to examine security returns during the event period is employed by Hite and Owers (1983). For each security $j$, we used the market model to calculate an excess return, or prediction error, for event day $t$ as follows:

$$
\mathrm{PE}_{j t}=R_{j t}-\left(\alpha_{j}+\beta_{j} R_{m t}\right)
$$

where $R_{j t}$ is the rate of return on security $j$ for event day $t$, and $R_{m t}$ is the rate of return on the CRSP value-weighted index on event day $t$. The CAR results are robust when using the equally weighted index. The coefficients $\alpha_{j}$ and $\beta_{j}$ are the ordinary least squares estimates of the intercept and slope, respectively, of the market model regression.

The estimation period is from $t=-200$ to $t=-51$ relative to the initial press date $t=0$ (the first reference to the upcoming transaction in the financial press). Our parameter estimates are based on the pre-event period (post-event period returns are not used for any purpose in this paper). Within 17 days of the completion date, one-half of our sample of firms go ex-dividend. After this date, the original securities represent only a fraction of the pre-existing firm.

Prediction errors are calculated for each security over the interval $t=-50, \ldots, L_{j}$, where $L_{j}$ is the number of trading days between press and completion for firm $j$. The cumulative prediction error from event day $T 1_{j}$ to event day $T 2_{j}$ is defined as:

$$
\mathrm{CPE}_{j}=\sum_{t=T 1_{j}}^{T 2_{j}} \mathrm{PE}_{j t}
$$

We cumulate over various intervals, some of which are of common length across securities (e.g., $t=-50, \ldots, 0)$ and some of which vary across securities (e.g., $t=-50, \ldots, L_{j}$ ). For a sample of $N$ securities, the mean cumulative prediction error is defined as:

$$
\mathrm{CPE}_{\mathrm{ave}}=1 / N \sum_{(j=1)}^{N} \mathrm{CPE}_{j}
$$

The expected value of $\mathrm{CPE}_{\mathrm{ave}}$ is zero in the absence of abnormal performance.

The test statistic described by Dodd and Warner (1983) is the mean standardized cumulative prediction error. To compute this statistic, the prediction error $\mathrm{PE}_{j t}$ is standardized by its estimated standard deviation $\mathrm{S}_{j t}$.

Of the 249 spin-offs we initially identified, ten were eliminated because they were not listed 200 days prior to the press date. The 
value of $s j$ is given by:

$$
s_{j t}=s_{j}^{2}\left(1+\frac{1}{D_{j}}+\left(R_{m \tau}-\bar{R}_{m}\right)^{2} / \sum_{\tau=1}^{D_{j}}\left(R_{m \tau}-\bar{R}_{m}\right)^{2}\right),
$$

where: $s^{2} j=$ residual variance for security $j$ from the market model regression. $D_{j}=$ number of observations during the estimation period, $R_{m t}=$ rate of return on the market index for day $t$ of the event period, $R_{m}=$ mean rate of return on the market index during the estimation period, and $R_{m t}=$ rate of return on the market index for day $r$ of the estimation period.

$$
\mathrm{SPE}_{j t}=\mathrm{PE}_{j t} / s_{j t}
$$

The standardized cumulative prediction error $\mathrm{SCPE}_{j}$ over the interval $t=T 1_{j}, \cdots-, T 2_{j}$ is

$$
\overline{\mathrm{SCPE}}_{j}=\sum_{t=T 1_{j}}^{T 2_{j}}, \mathrm{SPE}_{j t} / \sqrt{T 2_{j}-T 1_{j}+1} .
$$

The test statistic for a sample of $N$ securities is

$$
Z=\sum_{j=1}^{N} \overline{\mathrm{SCPE}_{j}} / \sqrt{N}
$$

Each $\mathrm{SPE}_{j t}$ is assumed to be distributed unit normal in the absence of abnormal performance. Under this assumption, $Z$ is also unit normal.

\section{Press date abnormal returns}

Results. Press day findings are in Table 1.

This is the equivalent calibration of abnormal returns relative to the first mention of the prospective spin-off in the financial newspapers. Our finding of $3.06 \%$ cumulative abnormal return for the immediate event interval $(-1,+1)$ is in the same order of magnitude of previous studies, starting with the foundational works of Hite and Owers and Schipper and Smith. It is a consistent finding by different researchers examining different time intervals that firms experience an immediate AR of $\sim 3 \%$ with the announcement of a planned spin-off. The interval $(-1$, +1 ) is employed to contrast the stock prices at the end of the day before the first press announcement and the day after. The day of the first press announcement of the upcoming spin-off is day 0 , but since it is not known whether the timing of the announcement was made before or after the 4:00 p.m. EST closing of markets, we look at the stock price at the end of day +1 and compare it to that at the end of day -1 .

Spin-offs involve just one firm, so there is no negotiating between firms, including the "open outcry" control contests carried in publicly traded shares. Despite his feature, in the individual day Ars, there is some indication of a minor price reaction before the formal announcement day $t=0$. Even with just one company being involved in the decision to spin-off a unit, there is some potential for "leakage" as the decision as to whether to have the spin-off is undertaken.

The announcement interval CARs of $\sim 3 \%$ have been consistent overall all time periods studied in various papers. This contrasts with how the CARs for acquiring firms in whole-firm acquisitions changed from positive ( $\sim 4 \%$ in the 1960 s) to in recent decades, becoming negative, between -2 and $-3 \%$. This is because when firms saw back in the 1960s that acquiring publicly traded firms could create value, more firms joined the auctions, bid up prices, and the potential to create value by buying firms was eroded, to the point where "winner's curse" is now the overall outcome.

A prominent corporate acquirer noted this evolution back in the 1960s. J. B. Fuqua acquired so many companies that he remains the individual who has been the chairman of the most NYSE listed firms. In an autobiography in his later years (he died in the early 2000s in his late 1980s), he noted that while he made money to the point of being on the Forbes 400 list of the wealthiest Americans of the time, that avenue of wealth creation competed away in the financial corporate control market for target firms. However, reflecting the unique single-firm nature of spin-off divestitures, their value creation potential has not dissipated over time.

\section{Spin-off distribution ex-dividend date}

Discussion of ex-dividend date abnormal returns. The first documented finding of the notable ex-dividend date abnormal returns associated with spin-offs dividends was Owers (1982) and Hite and Owers (1983). However, the first published paper focusing on this attribute of spin-offs dividends appears to be Copeland et al. (1987). They report an average wealth gain of 2.19 percent on exdates of 59 spin-offs during 1962 to 1981 and that these findings may be related to the bid-ask spread effect.

The first published paper to explore this ex-dividend effect in greater detail appears to be Vijh (1994). Employing a sample of 113 spin-offs over the 1964-1990 interval, he found an average excess return of 3.0 percent on ex-dates. Thus, on average, the target shareholders in stock-for-stock mergers earn an excess return of 1.5 percent on merger ex-dates.

When first identified, it was noted that this ex-day CAR might be challenging to explain from rational expectations perspectives because the ex-date is known with certainty. By the time the dividend is declared, details of the spin-off are public information. Vijh made an interesting observation that (at the time) these abnormal returns are within bounds placed by transaction costs to preclude arbitrage by purchasing before ex-dates and selling afterward (Vijh, 1994).

However, the findings presented in this current paper (Table 2) are similar to those calibrated by Copeland et al. During the interval between the two sample selection periods, transactions

\begin{tabular}{|c|c|c|c|c|c|c|c|c|c|c|}
\hline Days & $\mathbf{N}$ & $\begin{array}{l}\text { Mean cumulative } \\
\text { abnormal return }\end{array}$ & $\begin{array}{l}\text { Precision- } \\
\text { weighted CAAR }\end{array}$ & $\begin{array}{l}\text { Positive: } \\
\text { negative }\end{array}$ & Patell Z & $p$-value & $\begin{array}{l}\text { Portfolio } \\
\text { time-series } \\
\text { (CDA) t }\end{array}$ & $p$-value & $\begin{array}{l}\text { Generalized } \\
\text { sign } Z\end{array}$ & $p$-value \\
\hline$(-50,0)$ & 239 & $3.81 \%$ & $2.84 \%$ & $145: 94>>>$ & 4.403 & $<0.0001$ & 3.568 & 0.0002 & 3.748 & $<0.0001$ \\
\hline$(-10,0)$ & 239 & $4.18 \%$ & $3.29 \%$ & $158: 81>>>$ & 10.982 & $<0.0001$ & 8.437 & $<0.0001$ & 5.430 & $<0.0001$ \\
\hline$(-5,0)$ & 239 & $3.87 \%$ & $3.14 \%$ & $161: 78>>>$ & 14.181 & $<0.0001$ & 10.570 & $<0.0001$ & 5.818 & $<0.0001$ \\
\hline$(-1,0)$ & 239 & $2.40 \%$ & $2.42 \%$ & $159: 80>>>$ & 18.936 & $<0.0001$ & 11.374 & $<0.0001$ & 5.559 & $<0.0001$ \\
\hline$(-1,+1)$ & 239 & $3.06 \%$ & $2.76 \%$ & $162: 77>>>$ & 17.606 & $<0.0001$ & 11.838 & $<0.0001$ & 5.948 & $<0.0001$ \\
\hline$(+1,+5)$ & 239 & $0.08 \%$ & $-0.28 \%$ & 109:130 & -1.362 & 0.0865 & 0.233 & 0.4078 & -0.912 & 0.1810 \\
\hline
\end{tabular}
costs have come down dramatically, consistent with the hypothesis that the ex-day CAR is not the results of the inability

Table 1 CARS for identified intervals relative to $t=0$ (press date). 
to execute profitable trades around this price pattern. This supports Vijh's conclusion that the bid-ask spread effect or any other measurement errors do not cause the ex-date returns. Instead, these returns are based on stock prices representing greater than average market depth and are significant within several data partitions. The ex-date returns seem to arise from various microstructure considerations that make the combined stock less attractive than the separated stocks that start trading after the ex-date. Choi and Strong (1983) have reasoned that many small investors prefer to buy the post-split shares when issued shares sell for a premium. Vijh (1994) finds that the spinoff ex-date returns are of the same order as the combined whenissued premium on parent and subsidiary shares and that their correlation is very high.

The value of the parent shares before the spin-off must be partitioned as the spin-off takes effect. Should there be a systematic propensity to make an administrative partition that does not comport with the market's assessment of the value partition, then there is potentially some impact. However, given that the ex-day return includes the spun unit's value, to that extent, this explanation holds the limited potential to explain the finding.

This method of computing the size factor based on the exdividend day price is comparable to the adjustment factor CRSP uses for computing returns on the ex-dividend day, where the factors are:

$$
x=r x P / P p
$$

from which we impute:

$$
r x P J(P p+r x P,)=x /(1+x)
$$

When CRSP did not report distribution factors, we calculated them using the CRSP procedure. This raises the question of which unit, parent, or subsidiary, is being spun off. However, when we partition into large and small spin-offs, we run no misclassification risk since we break the sample at the median of 0.066 .
There is a unique factor associated with the payment of spinoff dividends that warrants examination as to potentially contributing to explaining the notable ex-day ARs. That feature is often associated with spin-off dividends to have the ex-date as the day AFTER the payment date. This is a major variation from the typical dividend payment dates: announcement of intent, declaration date, ex-date, and payment date. The primary reason given for this procedural subtlety is that "many" spin-offs are of sufficient size that they might trigger margin calls on the ex-date if the standard sequence of dividend-payments dates was followed. However, with the ex-date being the day AFTER payment of the stock dividend, the securities go immediately into margin purchasers' accounts. Thus, the potential for a margin call if the "standard sequence" was employed is avoided.

This means that some yet-to-be-created securities of the spun unit trade on a "when issued" (WI) basis. They cannot be delivered until after the ex-date. The trading of the WI yet-to-be-spun securities provides a market value that presumably would mitigate the challenge of partitioning the parent stock referred to previously. WI trading occurs when the security has been listed and posted for trading. Still, the certificate representing the security itself is not yet issued and available for settlement (the period for when-issued trading is usually $<1$ week). A potential avenue of research would be to examine whether WI trading or the lack thereof is a factor in the ex-day ARs using the sample of spin-offs and determine which have WI trading and whether that reduces the ex-day AR.

\section{Market microstructure considerations}

One of the motivations provided for spin-offs and contributing to the value creation of such transactions is that it allows for an enhanced investment opportunity set (IOS) to investors.

Several scenarios can be posited regarding share trading resulting from a spin-off and potential value implications. First, some shareholders who did not find the pre-spin-off firm attractive as an investment because of perceived over-

\begin{tabular}{|c|c|c|c|c|c|c|c|c|c|c|}
\hline$(-10,0)$ & 251 & $1.82 \%$ & $1.41 \%$ & 151:100>>> & 4.794 & $<0.0001$ & 4.164 & $<0.0001$ & 3.816 & $<0.0001$ \\
\hline$(-5,0)$ & 251 & $1.67 \%$ & $1.37 \%$ & 161:90 >>> & 6.287 & $<0.0001$ & 5.169 & $<0.0001$ & 5.079 & $<0.0001$ \\
\hline$(-1,0)$ & 251 & $1.69 \%$ & $1.38 \%$ & $162: 89>>>$ & 11.004 & $<0.0001$ & 9.059 & $<0.0001$ & 5.206 & $<0.0001$ \\
\hline$(-1,+1)$ & 251 & $1.92 \%$ & $1.62 \%$ & $162: 89>>>$ & 10.508 & $<0.0001$ & 8.377 & $<0.0001$ & 5.206 & $<0.0001$ \\
\hline
\end{tabular}

Table 2 CARs for identified intervals relative to the ex-dividend date.

\begin{tabular}{|c|c|c|c|c|c|c|c|c|c|c|}
\hline $\begin{array}{l}\text { Mean } \\
\text { cumulative days }\end{array}$ & $\boldsymbol{N}$ & $\begin{array}{l}\text { Precision portfolio } \\
\text { abnormal return }\end{array}$ & Weighted CAAR & $\begin{array}{l}\text { Positive: } \\
\text { negative }\end{array}$ & Patell Z & $\begin{array}{l}\text { Time- } \\
\text { series } p \text { - } \\
\text { value }\end{array}$ & $(C D A) t$ & $p$-value & Sign Z & $\begin{array}{l}\text { Generalized } \\
\text { p-value }\end{array}$ \\
\hline$(-50,0)$ & 160 & $-0.06 \%$ & $0.43 \%$ & $92: 68>>$ & 0.569 & 0.2847 & -0.061 & 0.4757 & 2.341 & 0.0096 \\
\hline$(-10,0)$ & 160 & $0.21 \%$ & $0.30 \%$ & $89: 71>$ & 0.935 & 0.1748 & 0.439 & 0.3304 & 1.867 & 0.0310 \\
\hline$(-5,0)$ & 160 & $0.20 \%$ & $0.28 \%$ & $92: 68>>$ & 1.097 & 0.1363 & 0.576 & 0.2824 & 2.341 & 0.0096 \\
\hline$(-1,0)$ & 160 & $0.10 \%$ & $0.17 \%$ & $91: 69>$ & 0.663 & 0.2536 & 0.468 & 0.3198 & 2.183 & 0.0145 \\
\hline$(-1,+1)$ & 160 & $0.65 \%$ & $0.63 \%$ & $102: 58>>>$ & 2.699 & 0.0035 & 2.604 & 0.0046 & 3.923 & $<0.0001$ \\
\hline$(+1,+5)$ & 160 & $0.83 \%$ & $0.48 \%$ & $89: 71>$ & 2.015 & 0.0220 & 2.582 & 0.0049 & 1.867 & 0.0310 \\
\hline
\end{tabular}

Table 3 CARs for identified intervals relative to the dividend declaration. 
diversification might now choose to invest in either the reduced parent or the newly creased spun-off firm.

Another scenario is that some mutual funds may be incentivized (due to their investment strategy) to acquire the newly created firm. Given the sequencing of the payment and ex-dates with some spinoffs, this could cause additional demand for the spun firm's shares when they become available. The contrast in ex-day ARs between those spin-offs involves "When-Issued" trading and those that do not might well provide insights into this empirical finding.

Dividend declaration date. Once developing all the details for a spin-off, the Directors are at a point when they can formally declare the spin-off dividend. Given the high level of visibility, analysis, and disclosure associated with spin-offs, whether the formal declaration has any value-impacting information is best answered by examining stock price reactions around this declaration date. Reflecting the pattern of presenting results developed in the preceding two segments,

Discussion of spin-off dividend declaration date abnormal returns. Again, reflecting the pattern previously established, Table 3 reports the interval CARs around the formal declaration of the spin-off dividend. These findings show a CAR over $(-1$, +1 ) of $0.65 \%$, a statistically significant response. Therefore, it seems the formal declaration of a spin-off dividend provides information to the market, and the final resolution of any uncertainty regarding the spin-off will be value-enhancing.

Discussion of entire spin-off event average CAR returns. Here, we calculate the average CAR from the first press report of a prospective spin-off until it is completed. Over this interval, Hite and Owers (1983) found an average CAR of 7\%. As noted previously, this is remarkably interesting because it is quite like the average size of the unit being spun-off, indicating that after the divestiture transaction has been completed, the value of the spun unit is essentially entirely an increase in the value of the divesting firm to the pre-spin-off stockholders.

Our findings for the average CARs over the entire interval are somewhat smaller than Hite and Owers' (1983). For the whole sample, the average CAR was $4.10 \%$. On preliminary examination of the specific firms in the sample, a small number had large negative CARs. Our examination of these small number of firms with CARs of over $20 \%$ negative over the entire interval shows that these firms experienced negative developments sometimes related to the spin-off. Excluding these firms resulted in an average whole-interval average CAR of $5.01 \%$.

The case of Nobel and Paragon illustrates the large negative whole-interval SCARs. On August 1, 2014, Noble spun off its standard-specification offshore oil drilling business to Noble's shareholders as a new entity-Paragon-while retaining its highspecification offshore oil drilling business. As is typical for spinoffs, the deal involved the incurrence of debt by Paragon, the transfer of assets to Paragon by Noble. Within a few months, oil and gas prices plummeted as a result of a global recession. On February 14, 2016, Paragon filed for chapter 11 protection. In addition, there was legal action brought against Nobel claiming inappropriate transfers to the spun-off Paragon.

Another infamous spin-off (not included in our sample) was that Marriott Corp separated out its troubled real-estate operations from its profitable hotel operations in 1993. As a result, the value of recently issued bonds fell by in the order of 20\%. The bondholders of Marriott almost immediately brought an action against claiming that the set of assets supporting the interest and principal payments had been reduced (Parrino, 1997). This potential was first formally documented by Galia and
Masulus (1976). The bondholders did not prevail in court, and this transaction helped spur the development of "Put Bonds."

\section{The monetary value created by spin-offs}

Despite the large volume of research into spin-off restructuring, there appears to date to have been little attention to or calibration of the dollar/monetary value that these transactions create. Since these transactions are voluntary and involve no negotiation with another firm, almost all spin-offs generate positive abnormal returns (Ars). The clear indication and implication are that they are creating economically material amounts of incremental value. This section will calibrate that monetary value creation for our sample, thus adding dimension to spin-offs' findings. We took the CARs over the entire interval for the spin-offs (from the first press date to payment of the special spin-off dividend) and applied that to the market capitalization the day before the first press date.

When we applied the described methodology to the firms in our sample, the total value created by these spin-offs from 2007 to 2017 was $\$ 95.17$ billion. The average value created for each firm in the sample is $\$ 0.423$ billion ( $\$ 423$ million). While the firms' size varied widely, this is a quite remarkable average monetary value creation for shareholders. The most extensive value creation was $\$ 8.915$ billion by Telephonos De Mexico in a significant spin-off.

Examining firms that lost value over the entire interval indicates that major adverse developments unrelated to the spin-off were the causes.

In summary, overall from 2007 to 2017 alone, spin-offs created almost $\$ 100$ billion incremental value. There is, therefore, evidence of both statistical significance and economic materiality as a result of spin-offs.

Summary of empirical findings. Our empirical analysis found that the stellar value-creating spin-off attributes first calibrated by Owers (1982) now 4 decades ago have been maintained into the recent past as the volume of such restructuring has increased dramatically. The initial announcement effect and attractive exdividend abnormal returns are still present. The formal declaration of a spin-off dividend resolves any residual uncertainty about the divestiture being completed and is associated with another significant CAR.

It is well-documented that spin-offs are associated with statistically significant abnormal returns. However, despite the reference to the implicit "economic materiality" of the associated equity/stock price changes, there has been little measurement of the impact in terms of monetary amounts. This paper calibrated the monetary/dollar value creation and documents the remarkable economic materiality of value creation by spin-offs.

\section{Conclusions}

This paper spans and reviews the whole interval from the first foundational published spin-off research papers from 1983 until 2021. In the sample selection section, we noted that the rate of spin-offs has increased relative to earlier times. While used in practice over many decades, it is only in the past 40 years that there has been systematic theoretical and empirical research into the motivations for and valuation consequences of voluntary spin-offs. These research findings of just how substantial the valuation consequences of spin-offs are may well have prompted the broader use of this restructuring strategy in practice. As in previous studies, we confirm and calibrate value changes associated with spin-offs to be statistically significant, but this paper's additional contribution measures monetary changes in market capitalizations that are economically material.

The combination of strengthening sophistication in investor portfolio composition might have prompted more firms to separate 
distinct and potentially incompatible operating strategic business units (SBUs) through spin-off divestitures. As portfolio theory and practice have developed along with research into large firms' financial performance, there has emerged a profile of underperformance by large, diversified firms. A classic example is General Electric, Inc. Once hailed as "the last of the successful conglomerates," it is by now held in very low regard for both dysfunctional operating attributes and the accompanying poor financial and investment performance. It is much preferred "pure-play" firms that focus on one (or a few closely related) lines of business and let investors accomplished the desired diversification by holding diversified financial portfolios of primarily "pure-play" firms.

Our empirical analysis finds that the spin-offs stellar valuecreating attributes have been maintained into the recent past as the volume of such restructuring has ballooned. The positive initial announcement effect and compelling and interesting ex-dividend abnormal returns are still present. The formal declaration of a spinoff dividend resolves any residual uncertainty about the divestiture being completed and is associated with another significant CAR. Empirical research calibrates the overall CAR over the entire interval from the initial press date to dividend distribution for our sample. It is well-documented that spin-offs are associated with statistically significant abnormal returns. Despite the reference to the implicit "economic materiality" of the associated equity/stock price changes, there has previously been a little measurement of the impact in terms of monetary amounts. The almost $\$ 100$ billion monetary/dollar calibration of the unique economic materiality of value created by spin-offs is a substantial incremental contribution of this paper.

\section{Data availability}

The datasets generated during the current study are available from the corresponding author on reasonable request.

Received: 23 March 2021; Accepted: 12 May 2021;

Published online: 03 June 2021

\section{References}

Aggarwal P, Garg S (2019) Restructuring through spin-off: impact on shareholder wealth. Manag Finance 45(10/11):1458-1468

Baker M, Wurgler J (2006) Investor sentiment and the cross-section of stock returns. J Finance 61:1645-1680

Berg D, Xu T, Powell R, Victoravich L (2020) Resolutions to the information disclosure dilemma: evidence from divested spin-offs. https://doi.org/ 10.5465/AMBPP.2020.17980abstract

Boudreaux KJ (1975) Divestiture and share price. J Financial Quant Anal 10:619-629

Chai D, Lin Z, Veld C (2017) Value-creation through spin-offs: Australian evidence. Aust J Manag 43(3):353-372

Chiu S (2020) Experiential learning, inter-firm imitation, and advice-seeking during corporate restructuring. https://doi.org/10.5465/AMBPP.2020.21597abstract

Choi D, Strong RA (1983) The pricing of when-issued common stock: a note. The Journal of Finance 38(4):1293-1298

Copeland RM, McKinnon S(1987) 'Financial distortion' and consolidation of captive finance subsidiaries in the general merchandising industry J Bus Finance account 14:77-97

Dann LY (1981) Common stock repurchases: an analysis of the returns to stockholders and bondholders. J Financial Econ 9:113-138

Dodd P, Warner JB (1983) On corporate governance: a study of proxy contests. J Financial Econ 11:401-438

Ellert JC (1976) Mergers, antitrust law enforcement and stock holder returns. J Finance 31:715-732

Feldman E, Amit R, Villalonga B (2019) Family firms and the stock market performance of acquisitions and divestitures. Strateg Manag J 40(5):757-780

Galai D, Masulis RW (1976) The option pricing model and the risk factor of stock. J Financial Econ 3:53-81

Helwege J, Liang N (2004) Initial public offerings in hot and cold markets. J Financial Quant Anal 39:541-569
Hite GL, Owers JE (1983) Sale divestitures: implications for sellers and acquirers, Working paper. Ohio State University, Columbus, $\mathrm{OH}$

Hite GL, Owers JE (1983) Security price reactions around corporate spin-off announcements. J Financial Econ 12:409-436

Jensen MC, Meckling WH (1976) Theory of the firm: managerial behavior, agency costs and ownership structure. J Financial Econ 3:305-360

Kalay A (1982) Stockholder-bondholder conflict and dividend constraints. J Financial Econ 10:211-233

Kim EH, McConnell JJ, Greenwood PR (1977) Capital structure rearrangements and me-first rules in an efficient capital market. J Finance 32:789-810

Kummer DR (1976) Valuation consequences of forced divestiture. J Econ Bus 4:130136

Lowry M (2003) Why does IPO volume fluctuate so much? J Financial Econ 67:3-40 Miller MH, Scholes MS (1978) Dividends and taxes. J Financial Econ 6:333-364

Myers SC (1977) Determinants of corporate borrowing. J Financial Econ 5:147-175

Navatte P, Schier G (2017) Spin-offs: accounting and financial issues across the literature. Account Audit Control 23(1):97-125

Owers JE (1982) Voluntary divestiture and security valuation: evidence and issues, Unpublished Ph.D. dissertation. The Ohio State University, Columbus, $\mathrm{OH}$, June 1982

Parrino R (1997) Spin-offs and wealth transfers: the marriott case. J Financial Econ 43:241-274

Pham D, Nguyen T, Pham T, Adhikari H (2020) Corporate divestiture decisions and long-run performance. J Behav Finance, https://doi.org/10.1080/ 15427560.2020 .1735389

Prezas AP, Symonian K (2015) Corporate divestitures: spin-offs vs. sell-offs. J Corp Finance 34(C):83-107

Rosenfeld JD (1984) Additional evidence on the relations between divestiture announcements and shareholder wealth. J Finance 39:1437-1448

Schipper K, Smith A (1983) Effects of recontracting on shareholder wealth: the case of voluntary spin-offs. J Financial Econ 12:437-467

Smith CW, Warner JB (1979) On financial contracting: an analysis of bond covenants. J Financial Econ 7:117-161

Stevenson M, Eilertsen J (2020) Five accounting considerations for divestitures and carveouts. Journal of Accountancy (December 2020), available at: https:// www.journalofaccountancy.com/news/2020/dec/accounting-considerationsfor-divestitures-and-carveouts.html

Teschner N, Paul H (2020) The impact of divestitures on shareholder wealth. Eur J Manage Bus Econ 30(1):55-7

Vermaelen T(1981) Common stock repurchases and market signalling J Financial Econ 9(2):139-183

Vijh AM (1994) The spin-off and merger ex-date effects. J Finance 49:581-609

\section{Acknowledgements}

The outstanding research assistance of Samantha van de Ven and Rangesh Vittal is enthusiastically commended. We are grateful for research funding support from the Harvard University Extension School and the facilitation by the Harvard Business School.

\section{Competing interests}

The authors declare no competing interests.

\section{Additional information}

Correspondence and requests for materials should be addressed to B.S.S.

Reprints and permission information is available at http://www.nature.com/reprints

Publisher's note Springer Nature remains neutral with regard to jurisdictional claims in published maps and institutional affiliations.

Open Access This article is licensed under a Creative Commons Attribution 4.0 International License, which permits use, sharing, adaptation, distribution and reproduction in any medium or format, as long as you give appropriate credit to the original author(s) and the source, provide a link to the Creative Commons license, and indicate if changes were made. The images or other third party material in this article are included in the article's Creative Commons license, unless indicated otherwise in a credit line to the material. If material is not included in the article's Creative Commons license and your intended use is not permitted by statutory regulation or exceeds the permitted use, you will need to obtain permission directly from the copyright holder. To view a copy of this license, visit http://creativecommons.org/ licenses/by/4.0/

(C) The Author(s) 2021 